УДК 681.516.75: 004.8: 632.08

\title{
АДАПТИВНА СИСТЕМА КЕРУВАННЯ ВИРОБНИЦТВОМ ЕНТОМОФАГІВ
}

\author{
Лисенко В.П. ${ }^{1}$, Чернова I.C. ${ }^{2}$ \\ ${ }^{1}$ - Національний університет біоресурсів і природокористування України \\ 2 - Інженерно-технологічний інститут «Біотехніка» НААН України \\ E-mail: ${ }^{1}$ lysenko@nubip.edu.ua, ${ }^{2}$ bioischernova@ukr.net
}

Copyright (C) 2018 by author and the journal "Automation technologies and business - processes. This work is licensed under the Creative Commons Attribution International License (CC BY). http://creativecommons.org/licanses/by/4.0
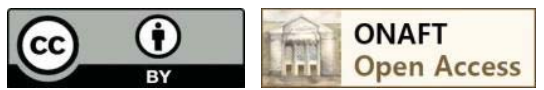

DOI:

Анотація. Стаття присвячена розробленню адаптивної системи керування виробництвом ентомофага бракон (Habrobracon hebetor), який є перспективним гусеничним паразитоїдом у біологічній боротьбі зі шкідниками сільськогосподарських культур.

Метою досліджень є підвищення ефективності виробництва ентомофагів иляхом розроблення системи керування із використанням інтелектуального алгоритму обробки інформації, зокрема, гібридної нейронної мережі прямого поширення сигналу.

Методи досліджень - ситуаційне керування, експериментальні дослідження в режимі реального часу, нечіткий висновок, чисельне інтегрування.

Розроблено адаптивну гібридну інтелектуальну систему керування температурою повітря боксу для лабораторного виробництва млинової вогнівки (Ephestia kuehniella), комахи-хазяїна ентомофага бракон.

Проведено дослідження системи в режимі реального часу із використанням структурної моделі в Simulink/MATLAB, ANFIS - peдакmopa, OPC Toolbox MATLAB, OPC-cepверa OWEN.RS485 i Fuzzy Logic Toolbox MATLAB.

Запропонована адаптивна система керування виробництвом ентомофагів дозволяє: підвищити ефективність виробництва за рахунок автоматизації складного виробничого процесу, зменшуючи при изьому вплив суб'єктивного фактору; підвищити точність підтримання температури повітря боксу для вирощування ентомокультур в умовах збурень.

Abstract. The article is devoted to the development of an adaptive production management system for the entomophage Habrobracon hebetor, which is a promising caterpillar parasitoid in biological control of crop pests.

The aim of the research is to increase the efficiency of the production of entomophages by developing a control system using an intelligent information processing algorithm, in particular, a hybrid neural network direct signal propagation.

Research methods - situational management, experimental studies in real time, fuzzy inference, numerical integration.

Developed an adaptive hybrid intelligent control system for air temperature of the box for laboratory cultivation of Ephestia kuehniella, the insect host entomophage Habrobracon hebetor.

The system has been studied in real time using a structural model in Simulink/MATLAB, OPC-server OWEN.RS485, ANFIS-editor, OPC Toolbox and Fuzzy Logic Toolbox MATLAB.

The proposed adaptive entomophage production management system allows to increase production efficiency due to of automating a complex production process, while reducing the influence of the subjective factor; improve the accuracy of maintaining the temperature of the air box for growing entomocultures in conditions of disturbances.

Ключові слова: виробництво ентомофагів, адаптивна система керування, режим реального часу, гібридна мережа, ефективність.

Key words: entomophage production, adaptive control system, real time mode, hybrid network, efficiency.

Актуальність. В теперішній час виробництво ентомофагів гарантованої якості є однією зі складових виробництва органічної продукції для збільшення популяції корисних комах у біологічному контролю шкідників сільськогосподарських рослин. При цьому таке виробництво являє собою складну біотехнологічну систему через 
наявність великої кількості взаємозв'язаних між собою підсистем (підготовки поживного середовища, вирощування комахи-хазяїна, оцінки якості ентомологічної продукції та ін.), цільові функції яких не співпадають 3 цільовою функцією загалом виробництва; значних сумарних витрат електроенергії на забезпечення оптимальних параметрів мікроклімату в зоні вирощування комах; функціонування в умовах невизначеності біологічного об'єкту, яка проявляється у його різній поведінці за дією сукупності факторів впливу, та вплив зовнішніх збурень (різке змінення температури та відносної вологості навколишнього середовища, припинення електропостачання, часткова втрата працездатності обладнання, його зношування, перемішування повітря боксу для розведення ентомокультур 3 повітрям зовнішнього приміщення).

На якість ентомологічної продукції суттєво впливає температура повітря. Так, при підвищенні температури повітря в зоні існування комах спостережується їх перегрівання та скорочення споживання кормів, що призводить до різкого скорочення плодючості [1].

Підвищити ефективність виробництва ентомофагів можливо за рахунок використання інтелектуальних алгоритмів обробки інформації. Для цього необхідно вдосконалити існуючу систему керування із двопозиційним регулятором [2] шляхом використання регуляторів на основі нечіткої логіки, гібридної нейронної мережі та ситуаційного управління.

Ситуаційне управління - найбільш перспективний метод розв'язання завдань із керування функціональними станами технічної системи в реальному масштабі часу, що дає змогу формувати рішення на основі порівняння поточної ситуації із заданим набором можливих керуючих впливів згідно із ситуацією, що склалася на поточний момент [3].

Аналіз останніх досліджень та публікацій. На сьогодні перспективним для розробки інтелектуальних систем керування виробничими процесами є використання стратегій управління на основі інтерактивного середовища Simulink/MATLAB i технології ОРС-комунікацій $[4,5,6]$ через можливість забезпечення зв'язку системи автоматизації виробничого процесу з віртуальною моделлю для проведення процесів управління в режимі реального часу.

Мета дослідження - підвищення ефективності виробництва ентомофагів шляхом розроблення системи керування із використанням інтелектуального алгоритму обробки інформації, зокрема, гібридної нейронної мережі прямого поширення сигналу.

Матеріали і методи дослідження. Об'єктом дослідження $є$ процес вирощування гусениць млинової вогнівки (Ephestia kuehniella) у виробництві ентомофага бракон (Habrobracon hebetor). Методи досліджень - ситуаційне керування, експериментальні дослідження в режимі реального часу, нечіткий висновок, чисельне інтегрування. Методика побудови адаптивної системи керування містить: формування вибірки для навчання мережі за результатами експериментальних досліджень системи керування температурою повітря боксу на основі двопозиційного регулятора [2] із врахуванням збурень (температури навколишнього середовища і приміщення, що межує з боксом), що склались на поточний момент часу; їі завантаження в ANFIS - редактор MATLAB, який реалізує систему нечіткого висновку Сугено у вигляді п'ятишарової нейронної мережі прямого поширення сигналу [7]; завдання функцій приналежності вхідних та вихідних терм-множин; визначення структури гібридної мережі; іiі навчання; визначення помилки мережі від кількості циклів навчання; тестування мережі; перегляд автоматично сформованих правил; розробку структурної моделі в Simulink/MATLAB; встановлення зв'язку ОРC Toolbox, OPC-сервера OWEN.RS485 i Fuzzy Logic Toolbox MATLAB; випробування адаптивної гібридної інтелектуальної системи керування в режимі реального часу; оцінку результатів випробувань.

При цьому вибір керуючого впливу зводиться до такого управління, що забезпечить виконання цільової функції мінімізацію похибки регулювання температури повітря боксу для розведення комах за модульним інтегральним критерієм.

Результати дослідження та їх обговорення. Розроблено адаптивну гібридну систему керування виробництвом ентомофага бракон, зокрема, керування температурою повітря боксу для вирощування млинової вогнівки. Для цього за результатами експериментальних досліджень (рис. 1) системи керування температурою повітря боксу на основі двопозиційного регулятора ТРМ202 ОВЕН при уставці регулятора $25,5^{\circ} \mathrm{C}$ та зоні його нечутливості $\pm 0,5{ }^{\circ} \mathrm{C}$ за температури навколишнього середовища $10^{\circ} \mathrm{C}$ і зовнішнього приміщення $19,6{ }^{\circ} \mathrm{C}$ сформовано вибірку (рис. 2 , а) для навчання гібридної мережі, яку завантажено в ANFIS - редактор MATLAB (рис. 2, б). Помилка навчання за 100 епох склала 0,000096203 (рис. 2, в). 


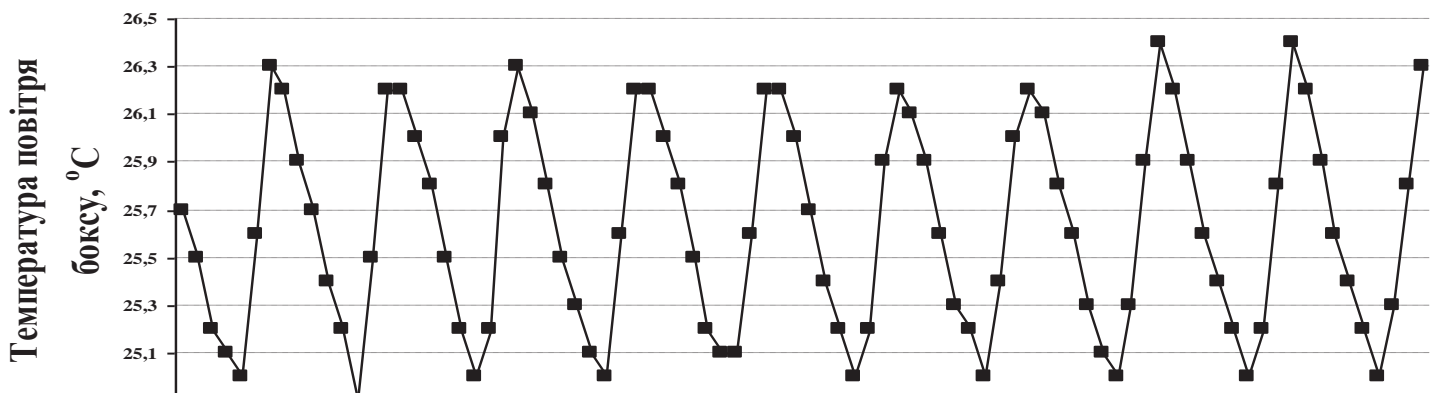

Рис. 1 - Результати роботи системи керування температурою повітря боксу на основі позиційного регулятора

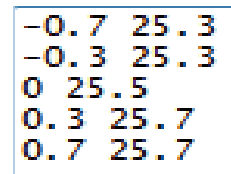

a)

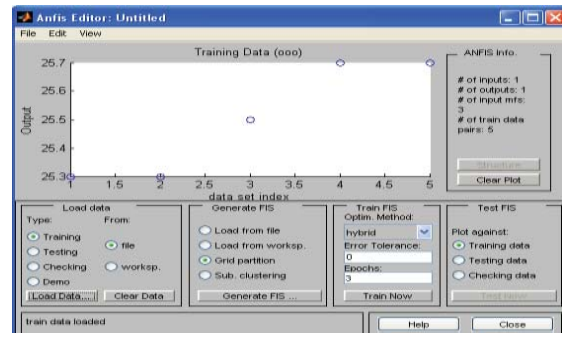

б)

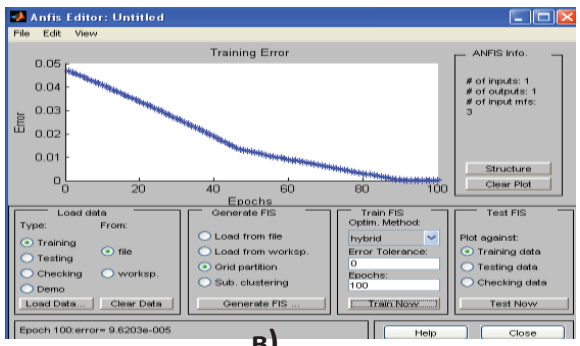

B)

Рис. 2 - Навчальна вибірка (a), ANFIS - редактор MATLAB (б) та результати навчання вибірки для 100 епох (в)

Гібридна мережа, структуру якої наведено на рис. 3, згенерована у вигляді п’ятишарової нейронної мережі прямого поширення сигналу. Середня помилка тестування навчальної вибірки (рис. 4) склала 0,000096203.

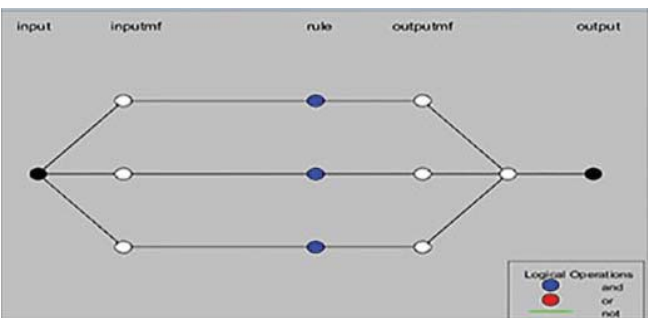

Рис. 3 - Згенерована гібридна мережа

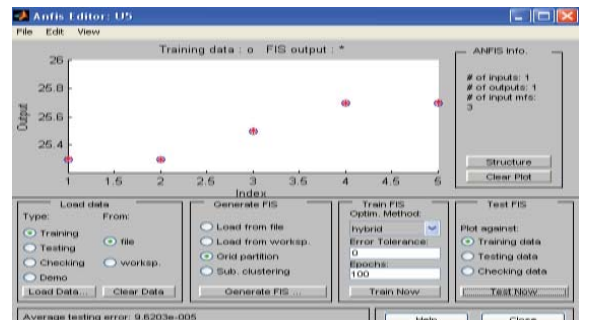

Рис. 4 - Результати тестування вибірки

Вхідною змінною (input1) мережі $є$ помилка регулювання температури системою керування на основі двопозиційного регулятора ТРМ 202 ОВЕН, вихідною (output) - уставка температури регулятора. Для вхідної змінної діапазоном [-0.7 0.7] терм-множинами $€$ in $1 \mathrm{mfl}$, in $1 \mathrm{mf} 2$, in $1 \mathrm{mf3}$ з трикутними функціями приналежності термів in1mf1:trimf [-1.234; -0.273; 0.207], in1mf2:trimf [-1.236; -0.01671; 1.229] та in1mf3:trimf [-0.1476; 0.2999; 1.236]. Для вихідної змінної діапазоном [25.3 25.7] терм-множинами $є$ out1mf1:constant [25.06], out1mf2:constant [25.6], out $1 \mathrm{mf3}$ :constant [25.78]. Значення терм-множин вихідної змінної визначались шляхом навчання мережі за гібридним методом (комбінація градієнтного спуску у вигляді алгоритму зворотного поширення помилки і методу найменших квадратів [7]). Етапами нечіткого висновку за Сугено є: And method - prod (реалізація логічної кон'юнкції за методом алгебраїчного добутку), Or method - probor (реалізація логічної диз'юнкції за методом алгебраїчної суми), Defuzzification (Метод дефаззіфікаціi) - wtaver (метод зваженого середнього).

Автоматично згенеровані продукційні правила бази знань системи нечіткого висновку мають вигляд (рис. 5).

П1: якщо input $1 \epsilon$ «in1mf1», то output $\epsilon$ «out1mf1»; П2: якщо input1 $\epsilon$ «in1mf2», то output $\epsilon$ «out1mf2»; П3: якщо input1 $\epsilon$ «in1mf3», тo output $\epsilon$ out1mf3». 


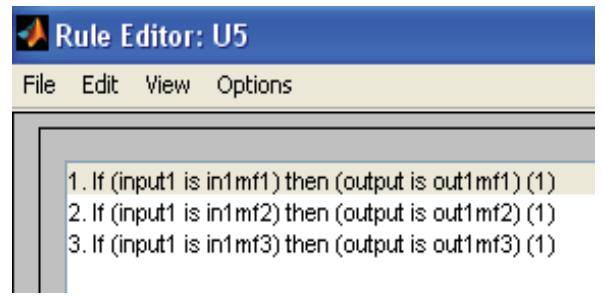

Рис. 5 - Вигляд бази знань гібридної мережі

У Simulink/MATLAB розроблено структурну модель адаптивної гібридної системи керування виробництвом ентомофагів (рис. 6). На рис. 7 наведено блок завдання уставки температури для вимірника-регулятора ТРМ202 OBEH.

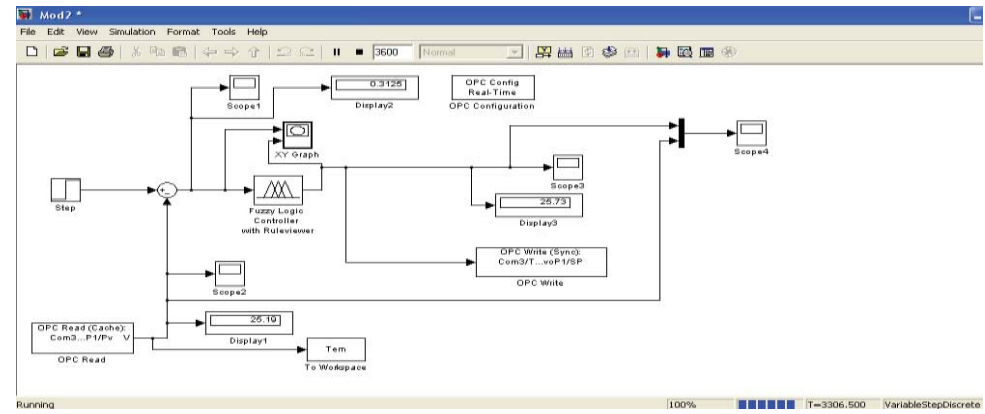

Рис. 6 - Структурна модель адаптивної гібридної системи

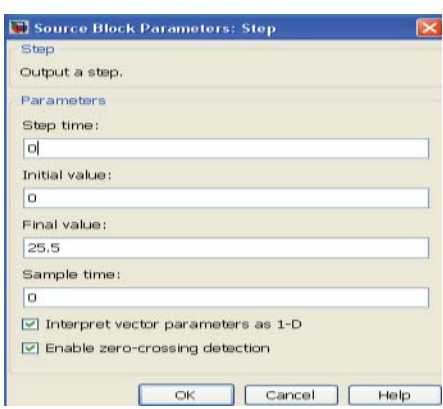

Рис. 7 - Настройка блоку Step моделі

Для забезпечення управління температурою повітря боксу в режимі реального часу через зв'язок Simulink/MATLAB з OPC-сервером OWEN.RS485 в модель додано блоки OPC Configuration, OPC Read и OPC Write.

На рис. 8, рис. 9 наведено блок налаштування параметрів контролю в реальному часі із визначенням ОРС-сервера OWEN.RS485 як OPC клієнта.

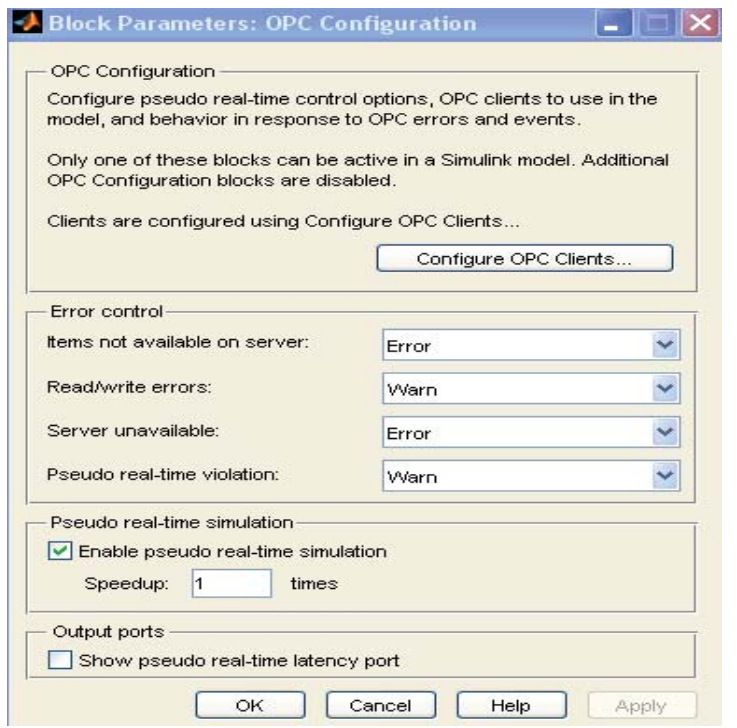

Рис. 8 - Блок налаштування параметрів контролю в реальному часі із встановленням кліснтів ОРС

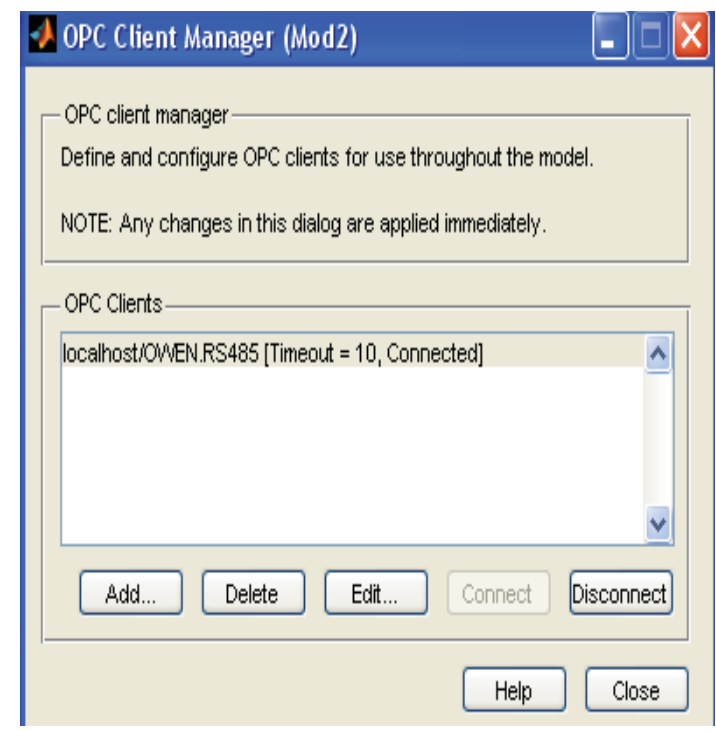

Рис. 9 - Процес визначення сервера OWEN.RS485 як OPC клієнта 
Блок OPC Read моделі (рис. 10) реалізує зчитування інформації про поточне значення температури повітря боксу; блок ОРC Write (рис. 11) - запис інформації про уставку температури вимірника-регулятора ТРМ202 ОВЕН у вказаний тег серверу OWEN.RS485.

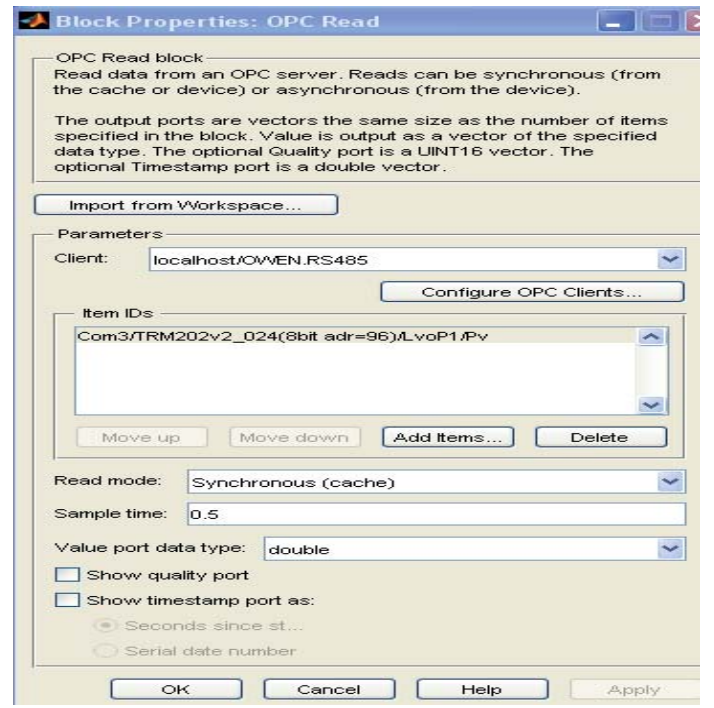

Рис. 10 - Настройка блоку OPC Read

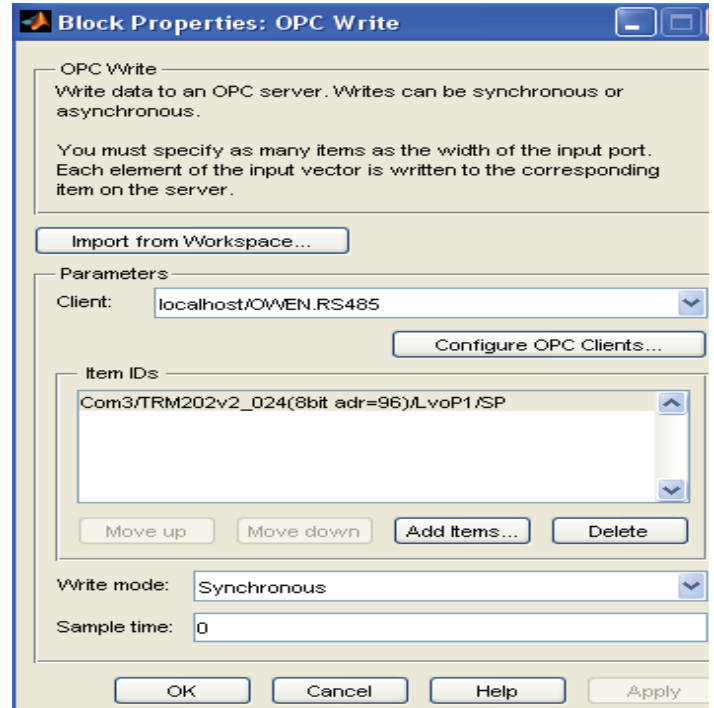

Рис. 11 - Настройка блоку ОРС Write

Підключення клієнта MATLAB до сервера OWEN.RS485 відбувалось за допомогою ОРC Toolbox MATLAB. На рис. 12 наведено вигляд підключення клієнта MATLAB до сервера OWEN.RS485, рис. 13 - працюючого сервера.

На рис. 14, рис. 15, рис. 16 представлено відповідно залежності уставки ТРМ 202 від похибки регулювання за нечітким висновком, в режимі реального часу та вигляд роботи системи нечіткого висновку в реальному часі.

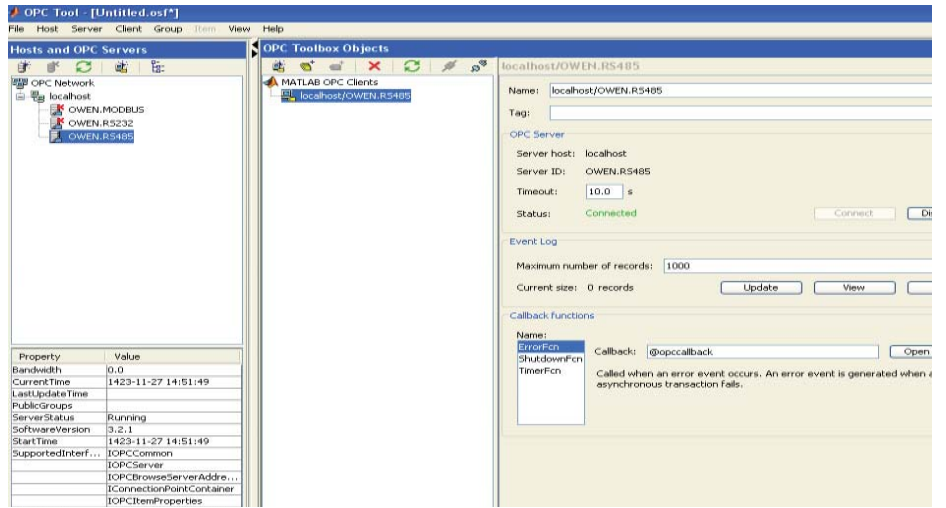

Рис. 12 - Підключення кліснта MATLAB до сервера OWEN.RS485

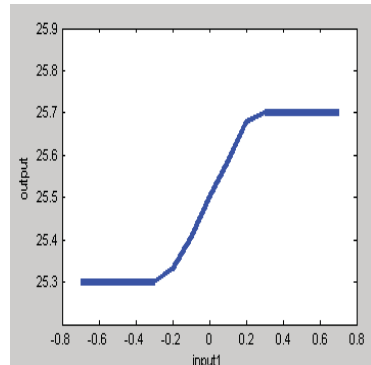

Рис. 14 - Залежність уставки ТРМ 202 від похибки регулювання за нечітким висновком

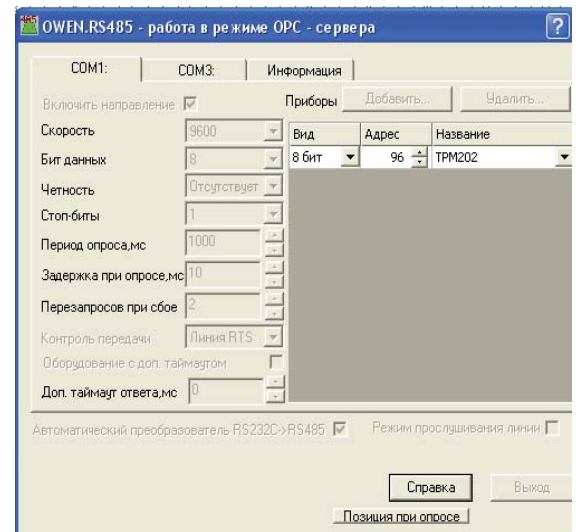

Рис. 13 - Вигляд працюючого сервера

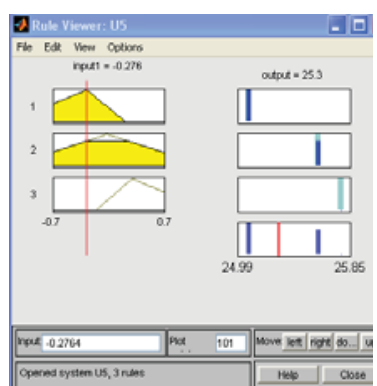

Рис. 16 - Вигляд роботи

Рис. 15 - Залежність уставки від похибки в режимі реального часу системи нечіткого висновку в реальному часі 
На рис. 17 наведено результат роботи адаптивної гібридної системи в реальному часі за температури навколишнього середовища $10^{\circ} \mathrm{C}$ i температури зовнішнього приміщення $19,6^{\circ} \mathrm{C}$ (віртуальний осцилограф Sсоре 4 у структурній моделі на рис. 6 відображає змінювання температури повітря боксу $\left(\theta^{\mathrm{b}}\right)$ та уставки регулятора $\left(\theta^{\mathrm{u}}\right)$ ТРМ 202 в реальному часі).

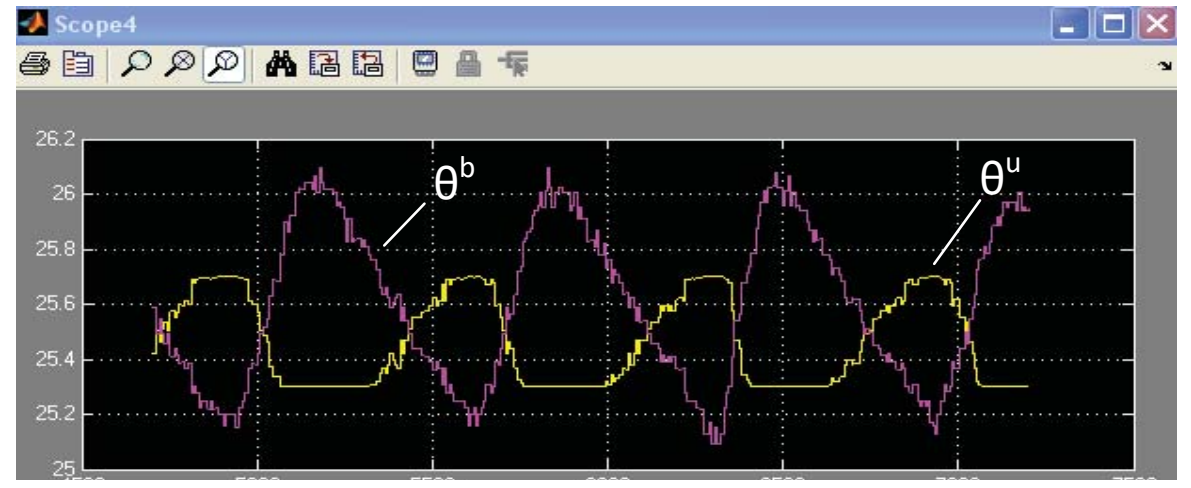

Рис. 17 - Результат роботи адаптивної гібридної системи в реальному

Критерієм якості управління обрано [8]:

$$
I=\frac{1}{t_{k}-t_{p}} \int_{t_{p}}^{t_{k}}|e(t)| d t \rightarrow \min ,
$$

де $t_{p}, t_{k}$ - відповідно час початку та закінчення інтервалу оцінювання процесу управління, с; e(t) - похибка змінювання температури повітря боксу за обраний інтервал оцінювання, ${ }^{\circ} \mathrm{C}$.

Порівнюючи роботу адаптивної системи (рис. 17) та системи на основі позиційного регулятора (рис. 1) за критерієм (1) визначено, що адаптивна система є більш ефективною: за інтервалом оцінювання 2040 с із використанням методу чисельного інтегрування значення інтегрального критерію системи 3 позиційним регулятором становить $0,65^{\circ} \mathrm{C}$, адаптивної системи $-0,52{ }^{\circ} \mathrm{C}$.

Таким чином, адаптивна гібридна система керування виробництвом ентомофагів на $20 \%$ покращує якість управління системою з позиційним регулюванням за модульним інтегральним критерієм.

Висновки і перспективи досліджень. Запропонована адаптивна система керування виробництвом ентомофагів дозволяе підвищити:

- ефективність виробництва за рахунок автоматизації складного виробничого процесу, зменшуючи при цьому вплив суб’ єктивного фактору;

- точність підтримання температури повітря боксу для вирощування ентомокультур в умовах збурень: на 37,5\% зменшена амплітуда коливань температури відносно уставки при управлінні на основі адаптивної гібридної системи.

\section{Література}

[1] Мельничук М., Блюм Я., Дубровін В., Таргоня В., Коломієць Ю., Бельченко В., Беспалов І. До питання обгрунтування та оцінювання біокліматичних показників біотехнологічних процесів на прикладі виробництва ентомологічного препарату трихограми. Техніка і технології АПК. 2011. № 8 (23). С. 34-37.

[2] Бельченко В.М., Чернова И.С. Система управления качеством энтомологической продукции с использованием информационных технологий. Сборник научных трудов «Защита растений». Минск. 2015. Вып. 39. С. $262-267$.

[3] Крючкова Л.П., Борисенко I.I. Застосування ситуаційного моделювання в управлінні технічними системами. Зв ’ззк. 2017. № 4. С. 43-47.

[4] Mrosko Marián, Miklovičová Eva. Real-time implementation of predictive control using programmable logic controllers. International Journal of Systems Applications, Engineering \& Development. 2012. Issue 1. Volume 6. P. 106-113.

[5] Бракоренко А.С. Тестирование и обеспечение качества программно-технических комплексов на основе использования виртуальных технологических объектов. Приборы и методы измерений. 2014. № 2 (9). С. 75-80.

[6] Дрозд О.В., Капулин Д.В. Моделирование и исследование автоматизированных систем управления и диспетчеризации технологических процессов. Исследования наукограда. 2013. № 3-4 (6). С. 39-45.

[7] Штовба С.Д. Введение в теорию нечетких множеств и нечеткую логику [Електронний ресурс]: URL: http://matlab.exponenta.ru/fuzzylogic/book1/index.php 
[8] Мовчан А.П., Степанець О.В. Адаптивні та параметрично-оптимальні системи управління. Навчальний посібник .К.: НТУУ «КПІ». 2011.108 с.

\title{
References
}

[1] Melnichuk M., Blyum Ya., Dubrovin V., Targonya V., Kolomiyec Yu., Belchenko V., Bespalov I. (2011). Do pitannya obgruntuvannya ta ocinyuvannya bioklimatichnih pokaznikiv biotehnologichnih procesiv na prikladi virobnictva entomologichnogo preparatu trihogrami [To the question of substantiation and evaluation of bioclimatic indices of biotechnological processes on the example of the production of the enthologic preparation of trichogramma] Tehnika $i$ tehnologiyi APK. 8 (23). P. 34-37. [in Ukraine].

[2] Belchenko V.M., Chernova I.S. (2015). Sistema upravleniya kachestvom entomologicheskoj produkcii s ispolzovaniem informacionnyh tehnologij [Entomological product quality management system using information technologies]. Sbornik nauchnyh trudov «Zashita rastenij». Minsk. Issue 39. P. 262-267. [in Russian].

[3] Kryuchkova L.P., Borisenko, I.I. (2017). Zastosuvannya situacijnogo modelyuvannya v upravlinni tehnichnimi sistemami [Application of situational modeling in the management of technical systems]. Zv'yazok. Issue 4. P. 43-47. [in Ukraine].

[4] Mrosko Marián, Miklovičová Eva (2012). Real-time implementation of predictive control using programmable logic controllers. International Journal of Systems Applications, Engineering \& Development. Issue 1. Volume 6. P. 106113.

[5] Brakorenko A.S. (2014). Testirovanie i obespechenie kachestva programmno-tehnicheskih kompleksov na osnove ispolzovaniya virtualnyh tehnologicheskih obektov [Testing and quality assurance of software and hardware systems based on the use of virtual technological objects]. Pribory i metody izmerenij. Issue 2 (9). P. 75-80. [in Russian].

[6] Drozd O.V., Kapulin D.V. (2013). Modelirovanie i issledovanie avtomatizirovannyh sistem upravleniya i dispetcherizacii tehnologicheskih processov [Modeling and research of automated control systems and process control]. Issledovaniya naukograda. Issue 3-4 (6). P. 39-45. [in Russian].

[7] Shtovba S. D. Vvedenie v teoriju nechetkih mnozhestv i nechetkuju logiku [Introduction to the theory of fuzzy sets and fuzzy logic]. URL: http://matlab.exponenta.ru/fuzzylogic/book1/index.php

[8] Movchan A.P., Stepanec' O.V. (2011). Adaptyvni ta parametrychno-optymal'ni systemy upravlinnja. Navchal'nyj posibnyk [Adaptive and parametric-optimal control systems. Tutorial]. K.: NTUU «KPI», 108 p. [in UУДК 681.5.015

\section{МОДЕЛЮВАННЯ СЕРЕДОВИЩА ВИСТОЮВАННЯ ХЛІБОБУЛОЧНИХ ВИРОБІВ ЯК ОБ'СКТА КЕРУВАННЯ}

\author{
Драндар А.В. ${ }^{1}$, Леонтьєва I.O. ${ }^{2}$, Хобін В.А. ${ }^{3}$ \\ Одеська Національна Академія харчових технологій, м. Одеса, Україна \\ ${ }^{1}$ Магістрант, ${ }^{2}$ Аспірант, ${ }^{3}$ професор, д.т.н. \\ ORCID: ${ }^{1}$ https://orcid.org/0000-0003-4045-2266, ${ }^{2}$ https://orcid.org/0000-0003-4276-6744, ${ }^{3}$ https://orcid.org/0000-0003-0238- \\ 8371 \\ E-mail: ${ }^{1}$ drandarik@gmail.com, ${ }^{2}$ romashka.leontieva.92@ukr.net, ${ }^{3}$ khobin@onaft.edu.ua
}

Copyright (C) 2018 by author and the journal "Automation technologies and business - processes.

This work is licensed under the Creative Commons Attribution International License (CC BY).

http://creativecommons.org/licanses/by/4.0

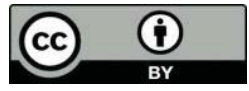

ONAFT

Open Access

DOI:

Анотація. Процес вистоювання тістових заготовок складається з багатьох фізико-механічних та біохімічних процесів, щзо ускладнює управління та отримання оптимальних показників якості на виході готового продукту. 